\title{
Protein composition of the phase I Coxiella burnetii soluble antigen prepared by extraction with trichloroacetic acid
}

\author{
G. FLORES-RAMÍREZ ${ }^{1}$, M. KMEŤOVÁ ${ }^{1}$, M. DANCHENKO ${ }^{1}$, E. ŠPITALSKÁ ${ }^{1}$, V. HAVLÍČEK ${ }^{2}$, L. ŠKULTÉTY ${ }^{1,2 *}$
}

${ }^{1}$ Institute of Virology, Biomedical Research Center Slovak Academy of Sciences, Dúbravska cesta 9, 84505 Bratislava, Slovak Republic;

${ }^{2}$ Institute of Microbiology of the CAS, v.v.i., Prague, Czech Republic

\begin{abstract}
Summary. - Q fever is a highly infectious, widespread airborne zoonosis caused by Coxiella burnetii bacterium. Humans usually acquire the disease by inhalation of contaminated aerosol produced by infected livestock. Vaccination is the most practical way for prevention and control of the disease in the exposed population. In this work, we reviewed the most important Q-fever outbreaks in Slovakia as well as the progress in vaccine development. One of them represents a soluble antigen complex produced by extraction with trichloroacetic acid from a highly purified C. burnetii phase I strain Nine Mile. It was developed at the Institute of Virology in Bratislava. The protein content of this vaccine was separated by gel electrophoresis and analyzed by mass spectrometry. The study has resulted in the identification of 39 bacterial proteins from which 12 were recognized as immunoreactive. Most of the proteins were involved in bacterium pathogenicity (41.6\%) and cell wall maintenance (25\%). Four of the immunoreactive proteins may possess the moonlighting activity. Definition of the vaccine components represents a prerequisite for vaccine standardization and approval by governmental authorities.
\end{abstract}

Keywords: Coxiella burnetii; Q fever; outbreaks in Slovakia; soluble antigen; chemovaccine; trichloroacetic acid; protein composition

\section{Introduction}

Coxiella burnetii is the causative agent of Q fever, a worldwide zoonotic disease with considerable economic impact in the livestock industry. Domestic animals as cattle, sheeps, and goats are the main reservoirs of $C$. burnetii and the source of Q fever in human.

The human infection is acquired by inhaling aerosolized microorganisms produced by infected livestock. The acute infection is typically asymptomatic or manifests as a febrile flu-like illness or pneumonia followed by a spontaneous recovery. In a small percent, patients may develop menin-

*Corresponding author. E-mail: viruludo@savba.sk; phone: +4212-59302418.

Abbreviations: 2 -DE = two-dimensional electrophoresis; SDS = sodium dodecyl sulfate; $\mathrm{Abs}=$ antibodies; $\mathrm{ACN}=$ acetonitrile; $\mathrm{CBB}=$ Coomassie Brilliant Blue; $\mathrm{CMR}=$ chloroform - methanol residue; $\mathrm{ECL}=$ enhanced chemiluminescence solution; $\mathrm{IEF}=$ isoelectric focusing; $\mathrm{ESI}=$ electrospray ionization; $\mathrm{FA}=$ formic acid; $\mathrm{MS}=$ mass spectrometry; $\mathrm{NM}=$ Nine Mile; $\mathrm{PI}=$ in phase $\mathrm{I} ; \mathrm{TCA}=$ trichloroacetic acid; $\mathrm{WCV}=$ whole inactivated bacterial cells goencephalitis, hepatitis, endocarditis that require intensive care. Chronic infection is usually accompanied by severe symptoms such as pulmonary infections, endocarditis or hepatitis.

In Europe, Q fever is widely extended, several outbreaks have been reported in Bulgaria, Germany, France, Hungary, and Poland. The largest outbreak arose between 2007-2010 in the Netherlands which resulted in 4026 human cases (Van der Hoek et al., 2010; Georgiev et al., 2013; Gyuranecz et al., 2014).

The first outbreak of Q fever in Slovakia was recognized in 1954 among agricultural workers. Epidemiological investigations revealed that the source of infection was a sheep flock imported from Romania. Shortly after, an infection of textile plant workers occurred (Rehacek, 1987). During the next decades, many small epidemics were reported from factories processing imported wool or hides as well as from sheep and cattle farms with imported animals (Table 1). Within the period of 1972-1982 large-scale vaccination of the ruminants and their veterinary control were implemented, which resulted in significant reduction of Q fever cases in the country (Kováčová et al., 2002). 
Table 1. Cases of $Q$ fever in Slovakia

\begin{tabular}{|c|c|c|c|}
\hline Year, place & Number of reported cases & Source of infection & References \\
\hline 1953, Western Slovakia & 25 textile plant workers & Sheeps imported from Romania* & Bardos et al. (1956) \\
\hline 1954, Western Slovakia & 51 farmworkers & Sheeps from the herd as above $e^{*}$ & Bardos et al. (1956) \\
\hline 1954, Gbely, Holíč & unknown & Cattle & Sádecký and Ábel (1978) \\
\hline 1954 , not mentioned & 40 workers & Processing of imported wool & Literák, Řeháček (1996) \\
\hline $\begin{array}{l}\text { 1957, Zemné, Nové Zámky } \\
\text { District }\end{array}$ & 28 humans & Dairy cows from Topolčany district & Literák, Řeháček (1996) \\
\hline 1959, not mentioned & 14 workers & $\begin{array}{l}\text { Processing of imported wool and } \\
\text { hides from Mongolia and China }\end{array}$ & Literák and Řeháček (1996) \\
\hline 1962, Sokolany, Košice District & 13 farmworkers & Cattle & Mittermayer et al. (1964), \\
\hline 1962, Bardejov District & $\begin{array}{l}10 \text { farmworkers on exchange visits }+2 \\
\text { clinically latent }+1 \text { infected lab. personnel }\end{array}$ & $\begin{array}{l}\text { Visiting recent and past foci of } \\
\text { Coxielosis }\end{array}$ & Janok et al. (1964) \\
\hline $\begin{array}{l}\text { 1962, Trenčianska Teplá, Trenčín } \\
\text { District }\end{array}$ & farmworkers & Imported rams from England & Literák and Řeháček (1996) \\
\hline 1963, Pinciná, Lučenec District & 5 humans & Dairy cows & Literák and Řeháček (1996) \\
\hline $\begin{array}{l}\text { 1963, Dobročská Lehota, } \\
\text { Lučenec District }\end{array}$ & 37 humans & Sheeps & Literák and Řeháček (1996) \\
\hline $\begin{array}{l}\text { 1965-1966, Sokolany, Kosice } \\
\text { District, Kečkovce, Svidnik } \\
\text { District }\end{array}$ & 139 farmworkers & Cattle & $\begin{array}{l}\text { Fricova et al. (1967), } \\
\text { Literák and Reháček (1996) }\end{array}$ \\
\hline $\begin{array}{l}\text { 1967, Slavošovice, Rochovice, } \\
\text { Rožňava District }\end{array}$ & 26 humans & Sheeps & Literák and Řeháček (1996) \\
\hline $\begin{array}{l}\text { 1969-1970, Budulov, Košice } \\
\text { District }\end{array}$ & 54 humans & Dairy cows & Literák and Řeháček (1996) \\
\hline $\begin{array}{l}\text { 1970, Balvany, Čalovo (Velký } \\
\text { Meder), Komárno District }\end{array}$ & 28 humans & Dairy cows & Literák and Řeháček (1996) \\
\hline 1975, Košice District & Farmworkers & Processing of sheep wool & Sádecký and Ábel (1978) \\
\hline $\begin{array}{l}1993 \text { (April), Jedlové Kostol'any, } \\
\text { Nitra District }\end{array}$ & $\begin{array}{l}113 \text { humans } \\
(84 \%) \text { aerosol transmission } \\
(16 \%) \text { farm workers }\end{array}$ & Goats (abortion) & Varga et al. (1997) \\
\hline 1993, Rimavská Sobota District & 11 farmworkers & Goats (abortion) & Varga et al. (1997) \\
\hline 2007, Košice, Košice District & $\begin{array}{l}\text { Veterinary students }(\geq 1: 800 \text { IgG in } 20 \text { students } \\
=8.2 \%)\end{array}$ & Professionally exposed & Dorko et al. (2008) \\
\hline
\end{tabular}

The largest outbreak of human Q fever in Slovakia began as a result of imports of 1181 goats from Bulgaria in September 1992. They were temporarily housed at Rimavská Sobota District, and 500 of them were transferred in January 1993 to the farm in the village Jedlové Kostolany, Nitra District (Dorko et al., 2012; Varga, 1997). Within the next two months, several abortions occured which resulted in two outbreaks. During the first one, 11 humans who were in direct contact with animals were infected (Dorko et al., 2012). The second epidemic, however, involved as many as 113 human cases (Table 1). Epidemiological investigations revealed that the source of infection was a contaminated aerosol in a local pub that arose from the clothing of farm workers who witnessed the abortion of one of the goat shortly before (Kováčová et al., 1998; Varga, 1997; Rehacek et al., 1996).

Q fever outbreaks usually occur from occupational exposure involving veterinarians, meat processing plant workers, dairy workers, livestock farmers, and laboratory personnel working with C. burnetii. Thus, prevention and control efforts should be directed primarily toward these groups and environments. The most efficient way of avoidance is a vaccination of the exposed populations. Although clinical data are lacking, vaccination should also be considered for persons who are at higher risk for development of chronic Q fever, including those with cardiac valve defects or prostheses, those with vascular aneurysms, and immunocompromised patients. Therefore, development of an effective vaccine against $\mathrm{Q}$ fever with minimal adverse reactions become a subject of interest to many researchers.

One of the first vaccines was prepared in 1948, only 12 years after the discovery of C. burnetii. This early whole cell vaccine (Smadel vaccine) was developed from formalinkilled and ether-extracted C. burnetii, containing 10\% yolk sac debris (Waag et al., 2002). Later, it was observed, that purification with the aim to remove chicken proteins and lipids, and isolation of the whole inactivated bacterial cells 
(WCV), contributed to less reactogenic and highly immunogenic preparations (Waag, 2007). Hendrix and Chen (2012) also showed that the vaccines prepared from virulent phase I microorganisms (WCV-PI) are more effective than the attenuated phase II vaccines (Arricau-Bouvery and Rodolakis, 2005). Nevertheless, this WCV was banned in the most countries around the world due to the prevalence of adverse effects (local and systemic reactions) that may occur in people with a history of $\mathrm{Q}$ fever or those that were previously vaccinated (Waag et al., 2007). Q-Vax ${ }^{\circledast}$ is the only commercially available human Q fever WCV-PI vaccine which is licensed in Australia. It is a monovalent vaccine developed in 1989 by the Commonwealth Serum Laboratories from formalin-inactivated purified whole cells of phase I C. burnetii Henzerling strain (Porter et al., 2011). It has a reported efficacy over $98 \%$ (Trubiano et al., 2012; Sellens et al., 2016; Waag et al., 2002) with protection up to 5 years (Ruiz and Wolfe, 2014). However, according to the rules of Australian National Vaccination Programme, strict pre-vaccination protocols such as serology and intradermal skin testing with diluted vaccine have to be implemented prior administration to avoid adverse effects (Sellens et al., 2016).

The acellular vaccines, or chemovaccines, are a new generation of vaccines with reduced adverse reactions that were shown to be as effective against Q fever as the whole cell vaccine (Parker et al., 2006). The chloroform-methanol residue vaccine (CMR) was prepared thanks to the cooperation of Rocky Mountain Laboratories with the US Army Research Institute for Infectious Disease in the late 70s. The phase I Henzerling strain inactivated with formalin was lyophilized and refluxed with a chloroform-methanol (4:1) mixture (Kersh et al., 2013). The prepared vaccine was able to induce protection in animals and human volunteers (Oyston and Davies, 2011; Fries et al., 1993). The chemovaccine, developed in former Czechoslovakia, is a soluble antigen complex produced by extraction of highly purified phase I C. burnetii Nine Mile strain EP3 using trichloroacetic acid (TCA). This extract contains proteins and LPS and it is highly reactogenic in humans (Kazar et al., 1982). In laboratory animals (mice and rabbits) the TCA extract induces the formation of antibodies against antigens 1 and 2, which was demonstrated by serodiagnosis as well as with opsonization phagocytosis and serum protective tests (Kazar et al., 1978). It also induces the cell-mediated component of immunity (Kazar et al., 1983). According to the record of the Department of Rickettsiology, Institute of Virology, BMC SAS, there were two major periods of immunization using this vaccine. The first was from 1972 to 1982 and the second from 1986 to 2004 during which 1421 and almost 300 individuals were vaccinated, respectively. They were mainly veterinarians, laboratory, farm and abattoir workers, and soldiers (Kazar et al., 1982, 1983). While significant protective efficacy and antibodies response were observed in the vaccinated individuals, no significant side effects were noted. Very mild systemic and local adverse reactions were described only in previously exposed individuals. Nevertheless, the vaccine production was stopped in 2002 due to insufficient knowledge of the composition of the vaccine. To fill the knowledge gap, we performed comprehensive characterization of the protein composition of the TCA extract.

\section{Material and Methods}

Preparation of the TCA extract of C. burnetii RSA 493. The optimal condition of extraction by TCA was applied (Lukacova et al., 1989). The purified inactivated C. burnetii RSA 493 phase I cells $\left(100 \mathrm{mg}\right.$ ) were resuspended in $20 \mathrm{ml}$ of Mill-Q $\mathrm{H}_{2} \mathrm{O}$ and $30 \mathrm{ml}$ of $16.7 \%$ (w/v) TCA solution was added to obtain the final concentration of $10 \%(\mathrm{w} / \mathrm{v})$ of TCA. The extraction was performed at $0^{\circ} \mathrm{C}$ for $45 \mathrm{~min}$ in an ice bath containing $\mathrm{NaCl}$ under constant stirring. After neutralization with sodium hydroxide, the mixture was spun down at $16,000 \mathrm{x} \mathrm{g}$ and $4^{\circ} \mathrm{C}$ for $40 \mathrm{~min}$. Three drops of $10 \%(\mathrm{v} / \mathrm{v})$ phenol was added to avoid microbial contamination. The supernatant was then dialyzed using 3,000 MW cut off membrane for 3 days against Mill- $\mathrm{Q} \mathrm{H}_{2} \mathrm{O}$ water ( 21 changed once a day) at $4^{\circ} \mathrm{C}$. This step was necessary to remove the salt. Then the sample was frozen at $-80^{\circ} \mathrm{C}$ followed by lyophilization for 3 days using Power dry PL3000 instrument (Thermo Scientific).

Two dimensional electrophoresis $(2-D E)$. Aliquots $(500 \mu \mathrm{g})$ of the lyophilized extract were dissolved in a sample buffer $(8 \mathrm{~mol} / \mathrm{l}$ Urea, $2 \mathrm{~mol} / \mathrm{l}$ thiourea, $1 \%(\mathrm{v} / \mathrm{v})$ ASB14, $1 \%(\mathrm{w} / \mathrm{v})$ Triton X-100) containing $1 \%(\mathrm{v} / \mathrm{v})$ of carrier ampholytes $\mathrm{pH}$ range 3-10 or 4-7 (GE Healthcare), and $1.7 \%$ of DeStreak reagent (GE Healthcare). Immobilized $\mathrm{pH}$ gradient strips ( $\mathrm{pH} 3-10$ or $\mathrm{pH} 4-7,18 \mathrm{~cm}$, GE Healthcare, Sweden) were passively rehydrated overnight (approx. $16 \mathrm{~h}$ ) in the dark at RT, then placed into Multiphor II apparatus (GE Healthcare, Sweden) and isoelectric focusing was performed using the following protocol; $100 \mathrm{~V}$ in gradient for $1 \mathrm{~h}, 500 \mathrm{~V}$ in gradient for $1 \mathrm{~h}, 1000 \mathrm{~V}$ in gradient for $1 \mathrm{~h}, 6,000 \mathrm{~V}$ in gradient for $3 \mathrm{~h}$, and 6,000V for $18 \mathrm{~h}$. The strips were then rinsed in deionized water and incubated in equilibration buffer (50 mmol/l Tris- $\mathrm{HCl}, \mathrm{pH} 8.8,6 \mathrm{~mol} / \mathrm{l}$ urea, 30\% (v/v) glycerol, $2 \%(\mathrm{w} / \mathrm{v})$ SDS containing 1\% (w/v) dithiothreitol (DTT, Sigma-Aldrich)) for $15 \mathrm{~min}$, followed by $4 \%(\mathrm{w} / \mathrm{v})$ iodoacetamide (IAA, Sigma-Aldrich) with $0.08 \%(\mathrm{w} / \mathrm{v})$ bromphenol blue. The second dimension separation was carried out on $16 \%$ polyacrylamide gels $(20 \mathrm{~cm} \times 20 \mathrm{~cm} \times 1 \mathrm{~mm})$ in Tris-glycine running buffer, using a Protean XL (Bio-Rad, USA) device. It was performed at $5 \mathrm{~mA} / \mathrm{gel}$ for $60 \mathrm{~min}$, followed by $45 \mathrm{~mA} / \mathrm{gel}$ until tracking dye migrated to the bottom of the gels. Protein spots were visualized with colloidal Coomassie Brilliant Blue (CBB) or used for Western blot.

Western blot. After the electrophoresis, the gel was washed for 5 min in Milli-Q water. A PVDF membrane $0.22 \mu \mathrm{m}$ (Merck, Germany) was activated with methanol, and the proteins were transferred using a semi-dryblotting apparatus (Multiphore II, Amersham). The voltage was set according to gels size (surface area $\left(\mathrm{cm}^{2}\right)^{\star} 0.8$ ). The membrane was blocked with $5 \%$ non-fat dry milk (Biorad) in PBS-Tween $0.1 \%$ 


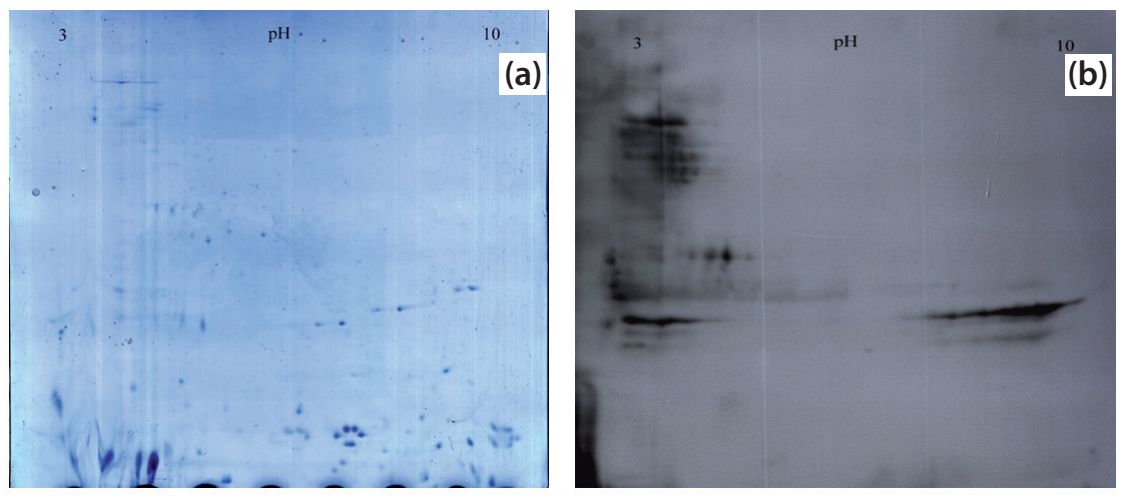

Fig. 1

(a) The representative 2-DE gel (3-10pI) and (b) Western blot analysis of phase I C. burnetii RSA soluble antigen

(PBS-T) overnight at $4^{\circ} \mathrm{C}$. Then, it was five times washed with PBS-T and incubated for $2.5 \mathrm{~h}$ in 1:200 diluted rabbit serum containing polyclonal antibody (to the Phase I \& II C.burnetii antigens) in $2.5 \%$ non-fat dry milk at room temperature (RT). The membrane was washed 5 times for $5 \mathrm{~min}$ with $200 \mathrm{ml}$ of PBS-T and incubated with secondary antibody (IgG HRP-linked 1:1,500 Polyclonal Swine, Anti-Rabbit Immunoglobulin, Dako) for $1 \mathrm{~h}$ in $2.5 \%$ non-fat dry milk in PBS-T at RT. Finally, the membrane was washed five times with PBS-T and developed by ECL system (GE Healthcare).

Trypsin digestion and mass spectrometry analyses. The excised spots were washed with agitation in $50 \%(\mathrm{v} / \mathrm{v})$ acetonitrile (ACN) (Merck, Germany) in $50 \mathrm{mmol} / 1 \mathrm{NH}_{4} \mathrm{HCO}_{3}$ (Ambic; Fluka,) at RT. After complete destaining, gel pieces were dehydrated with $100 \%$ ACN for $10 \mathrm{~min}$ at RT, reduced in $10 \mathrm{mmol} / \mathrm{l} \mathrm{DTT}$, and alkylated with $50 \mathrm{mmol} / \mathrm{l}$ iodoacetamide. The gel plugs were washed and dehydrated again with $100 \% \mathrm{ACN}$, and then incubated for $14-16 \mathrm{~h}$ at $37^{\circ} \mathrm{C}$ in digestion solution (10 $\mathrm{ng} / \mu \mathrm{l}$ of lyophilized sequencing grade modified trypsin (Promega, USA). The resulting peptides were acidified in extraction solution (1\% (v/v) formic acid (FA, Sigma Aldrich) in 5\% (v/v) ACN) followed by dehydration of the gel pieces in $70 \% \mathrm{ACN}$. The tryptic peptides were analyzed by automated nanoflow reversephase chromatography using the nanoAcquity UPLC system coupled to a Q-TOF Premier (Waters, UK) as described earlier (Skultety et al., 2011). The data were processed using the ProteinLynx Global Server (PLGS) v. 3.0 (Waters, UK). All data were lock spray calibrated against [Glu1]-Fibrinopeptide B (Sigma Aldrich, USA). The results were searched against the full proteome sequences derived from $C$. burnetii Nine Mile phase I which was downloaded from UniProt (in October 2016). Tentative peptide and protein identifications were ranked, and scored by their relative correlation to a number of wellestablished models of known and empirically derived physicochemical attributes of proteins and peptides. During database searches, one missed cleavage site was allowed. The precursor peptide mass tolerance was set to $\pm 20 \mathrm{ppm}$, and fragment mass tolerance to \pm 40 ppm. The search was performed with Cys carbamidomethylation and Met oxidation as fixed and variable modifications, respectively.
A minimum of two matched peptides and three or more consecutive fragment ions from the same series were required for protein identification. Protein identifications were accepted after manual inspection of probabilistic based PLGS assignment at $95 \%$ confidence level. Only those proteins are listed in the tables which were found at least twice out of three replicates.

\section{Results and Discussion}

In order to reveal protein composition of the soluble antigen used as a chemovaccine, the purified C. burnetii cells in phase I was subjected to extraction with TCA. The proteins were then resolved within the $\mathrm{pI}$ range 3-10 and mass range $15-150 \mathrm{kDa}$ using 2-DE. The analyses were performed on samples prepared in two biological replicates. A representative gel is shown in Fig. 1a. Image analysis revealed 82 protein spots which were reproducibly detected on CBB-stained gels.

The protein spots were excised from the gels, digested with trypsin, and analyzed by LC-MS/MS. Subsequently, data were processed by PLGS and the experimentally recorded MS spectra matched against the fully sequenced C. burnetii Nine Mile phase I database. Specifically, 39 proteins were identified (Table 2). The $10 \mathrm{kDa}$ chaperonin was found in six $(4,5,70,71,72,73)$ spots, the hypothetical exported protein CBU_1095 was identified in five $(14,16,17,58,59)$ spots, and the Tol system periplasmic component $\operatorname{ybgF}(52,53,54$, 62), uncharacterized protein CBU_0089a $(12,19,71,72)$, and $50 \mathrm{~S}$ ribosomal protein L7/L12 $(6,7,74,75)$ in four spots. The others were recognized in less than 3 spots. Most of the identified proteins (42\%) were associated with cytoplasm, $17 \%$ with the periplasm, $8 \%$ with the inner membrane, and $33 \%$ with the outer membrane of the bacterium (Fig. 2a). Interestingly, as many as $41 \%$ of the identified immunoreactive proteins may have moonlighting activity. 
Table 2. Identified proteins resolved from the TCA extract of $C$. burnetii cells

\begin{tabular}{|c|c|c|c|c|c|c|c|c|c|c|c|}
\hline 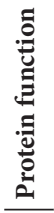 & 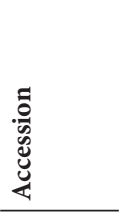 & 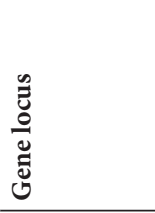 & 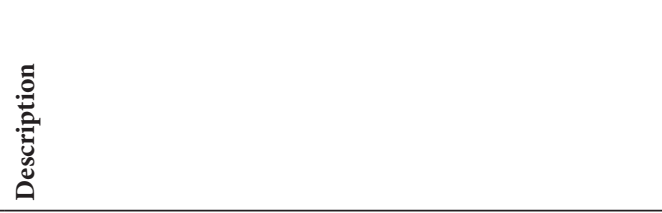 & 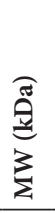 & 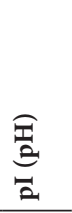 & $\begin{array}{l}\text { पे } \\
\text { है } \\
\text { है } \\
\text { के }\end{array}$ & 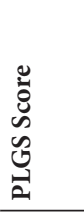 & 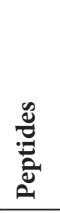 & 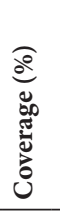 & 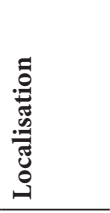 & 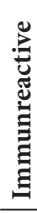 \\
\hline M & B5QS73 & CBU_0089a & Uncharacterized protein CBU_0089a & 12 & 10,3 & $12,19,71,72$ & 3806 & 10 & 53 & $\mathrm{U}$ & \\
\hline $\mathrm{T}$ & Q83F57 & CBU_0092 & Tol system periplasmic component ybgF & 34 & 6,5 & $52,53,54,62$ & 3015 & 25 & 30 & $\mathrm{P}$ & $\mathrm{X}$ \\
\hline $\mathrm{U}$ & Q83F41 & CBU_0110 & Hypothetical exported protein CBU_0110 & 18 & 9,3 & $36,39,40$ & 9472 & 25 & 38 & $\mathrm{U}$ & \\
\hline $\mathrm{U}$ & Q83F37 & CBU_0114 & UPF0234 protein CBU_0114 & 18 & 9,0 & 24 & 1157 & 14 & 34 & $\mathrm{C}$ & \\
\hline A & Q83F36 & CBU_0115 & Transcriptional regulator MraZ & 17 & 5,1 & 47 & 4241 & 16 & 41 & $\mathrm{C}$ & \\
\hline $\mathrm{D}$ & Q83AQ8 & CBU_0182 & Superoxide dismutase $[\mathrm{Cu}-\mathrm{Zn}]$ sodC & 21 & 9,6 & 44,45 & 2611 & 8 & 38 & $\mathrm{P}$ & \\
\hline $\mathrm{T}$ & Q83ET5 & CBU_0225 & Transcription termination/antitermination protein NusG & 22 & 8,9 & 25,56 & 2581 & 10 & 29 & $\mathrm{C}$ & \\
\hline $\mathrm{R}$ & P0C8S3 & CBU_0229 & $50 \mathrm{~S}$ ribosomal protein $\mathrm{L} 7 / \mathrm{L} 12$ & 13 & 4,5 & $6,7,74,75$ & 16932 & 19 & 37 & $\mathrm{C}$ & \\
\hline $\mathrm{R}$ & Q83EL5 & CBU_0304 & Translation initiation inhibitor & 16 & 9,0 & 11 & 2978 & 12 & 14 & $\mathrm{C}$ & \\
\hline $\mathrm{E}$ & Q83EL2 & CBU_0307 & Outer membrane protein CBU_0307 & 25 & 10,1 & 49,51 & 4491 & 21 & 44 & $\mathrm{O}$ & $\mathrm{X}$ \\
\hline $\mathrm{U}$ & B5QS99 & CBU_0562a & Uncharacterized protein CBU_0562a & 15 & 6,9 & $9,71,72$ & 13213 & 23 & 35 & $\mathrm{U}$ & \\
\hline $\mathrm{J}$ & Q83DT1 & CBU_0612 & Outer membrane protein ompH & 19 & 10,2 & $41,42,43$ & 28438 & 53 & 68 & $\mathrm{P}, \mathrm{O}$ & \\
\hline $\mathrm{J}$ & P51752 & CBU_0630 & Peptidyl-prolyl cis-trans isomerase Mip & 26 & 10,2 & 50,66 & 1367 & 18 & 31 & $\mathrm{O}$ & $\mathrm{X}$ \\
\hline $\mathrm{R}$ & Q83D76 & CBU_0864 & $30 \mathrm{~S}$ ribosomal protein $\mathrm{S} 6$ & 15 & 7,9 & 20 & 2435 & 15 & 36 & $\mathrm{C}$ & \\
\hline $\mathrm{R}$ & Q83D73 & CBU_0867 & 50 S ribosomal protein $\mathrm{L} 9$ & 17 & 6,2 & 10 & 1539 & 8 & 30 & $\mathrm{C}$ & \\
\hline $\mathrm{T}$ & Q83D29 & CBU_0915 & Enhanced entry protein enhB.1 & 19 & 8,7 & 22,23 & 5305 & 16 & 23 & $\mathrm{U}(\mathrm{MA})$ & \\
\hline $\mathrm{D}$ & Q83D04 & CBU_0943 & Rhodanese-related sulfurtransferase & 17 & 8,8 & 35 & 2223 & 13 & 38 & $\mathrm{U}$ & \\
\hline $\mathrm{J}$ & Q83CZ8 & CBU_0952 & adA protein & 26 & 9,3 & $28,29,33$ & 5256 & 37 & 41 & $\mathrm{O}$ & $\mathrm{X}$ \\
\hline $\mathrm{D}$ & Q83CY8 & CBU_0963 & Putative peroxiredoxin bcp & 17 & 8,0 & 21 & 9546 & 22 & 45 & C (MA) & \\
\hline $\mathrm{U}$ & Q83CL9 & CBU_1095 & Hypothetical exported protein CBU_1095 & 20 & 7,1 & $14,16,17,58,59$ & 15173 & 18 & 36 & $\mathrm{U}$ & \\
\hline $\mathrm{U}$ & Q83CI0 & CBU_1135 & Hypothetical exported protein CBU_1135 & 16 & 9,3 & 41 & 6194 & 9 & 57 & S & \\
\hline M & Q83C87 & CBU_1241 & Malate dehydrogenase mdh & 35 & 4,9 & 54 & 2022 & 13 & 20 & $\mathrm{C}$ & $\mathrm{X}$ \\
\hline $\mathrm{J}$ & O87712 & CBU_1290 & Chaperone protein DnaK & 71 & 5,0 & 1 & 1067 & 21 & 25 & C (MA) & $\mathrm{X}$ \\
\hline $\mathrm{T}$ & Q83C41 & CBU_1293 & Protein GrpE & 23 & 5,2 & 48 & 3338 & 18 & 27 & $\mathrm{C}$ & \\
\hline A & Q9X5U9 & CBU_1385 & Elongation factor Ts & 32 & 5,8 & 61,63 & 2466 & 17 & 35 & $\mathrm{C}$ & \\
\hline A & Q83BN9 & CBU_1464 & DNA-binding protein $\mathrm{HU}$ & 10 & 10,0 & 39,40 & 16895 & 16 & 40 & C & \\
\hline $\mathrm{T}$ & Q83BI9 & CBU_1519 & Protein-export protein SecB & 18 & 4,3 & 46 & 1303 & 6 & 19 & I & $\mathrm{X}$ \\
\hline $\mathrm{U}$ & Q83BB8 & CBU_1594 & GatB/YqeY domain protein & 17 & 5,9 & 13 & 3823 & 8 & 26 & $\mathrm{C}$ & \\
\hline $\mathrm{T}$ & Q83B63 & CBU_1652 & Icm X protein & 41 & 6,0 & 65 & 1092 & 11 & 17 & $\mathrm{U}$ & \\
\hline $\mathrm{U}$ & Q83B41 & CBU_1677 & Hypothetical cytosolic CBU_1677 & 17 & 6,2 & $15,18,57$ & 4250 & 23 & 75 & $\mathrm{C}$ & \\
\hline $\mathrm{J}$ & P19685 & CBU_1708 & Superoxide dismutase $[\mathrm{Fe}]$ sodB & 22 & 6,2 & 26,27 & 3427 & 12 & 26 & $\mathrm{P}(\mathrm{MA})$ & $\mathrm{X}$ \\
\hline M & Q83B07 & CBU_1715 & Glycine cleavage system $\mathrm{H}$ protein gcvH & 15 & 3,8 & 55,67 & 5919 & 8 & 44 & $\mathrm{C}$ & $\mathrm{X}$ \\
\hline J & P19421 & CBU_1718 & $60 \mathrm{kDa}$ chaperonin GroEL & 58 & 5,0 & 68 & 3910 & 46 & 48 & C (MA) & $\mathrm{X}$ \\
\hline $\mathrm{T}$ & P19422 & CBU_1719 & $10 \mathrm{kDa}$ chaperonin & 10 & 5,0 & $4,5,70,71,72,73$ & 18554 & 16 & 99 & $\mathrm{C}$ & \\
\hline M & Q83AV0 & CBU_1778 & Fructose-bisphosphate aldolase fabA & 40 & 5,3 & 76,77 & 687 & 8 & 25 & C (MA) & $\mathrm{X}$ \\
\hline $\mathrm{U}$ & B5QSG2 & CBU_1847b & Uncharacterized protein CBU_1847b & 13 & 8,5 & 37,38 & 18406 & 33 & 53 & $\mathrm{U}$ & \\
\hline M & Q83AI4 & CBU_1902 & Peptidase, M16 family & 52 & 6,3 & 64 & 1120 & 10 & 20 & $\mathrm{P}$ & \\
\hline $\mathrm{J}$ & H7C7D7 & CBU_1910 & Outer membrane protein com 1 & 28 & 9,4 & $30,31,32$ & 7924 & 20 & 31 & $\mathrm{O}$ & $\mathrm{X}$ \\
\hline $\mathrm{U}$ & Q83A32 & CBU_2079 & Uncharacterized protein CBU_2079 & 14 & 8,6 & 34 & 3902 & 16 & 19 & $\mathrm{U}$ & \\
\hline
\end{tabular}

The highest PLGS score, coverage, and numbers of peptides identified are shown. Localization: $\mathrm{C}=$ cytoplasmic, $\mathrm{MA}=$ protein with potential moonlighting activities, $\mathrm{O}=$ outer membrane protein, $\mathrm{I}=$ inner membrane, $\mathrm{P}=$ periplasmic protein, $\mathrm{U}=$ unknown. Immunoreactive proteins: $\mathrm{X}=$ present. Function: $\mathrm{M}=$ metabolic pathway, $\mathrm{E}=$ cell envelope integrity, $\mathrm{T}$ = protein \& peptide secretion \& trafficking, $\mathrm{J}=$ pathogenicity \& pathogenesis, $\mathrm{A}=$ transcription, $\mathrm{D}=$ detoxification, $\mathrm{R}=$ translation 
(a)

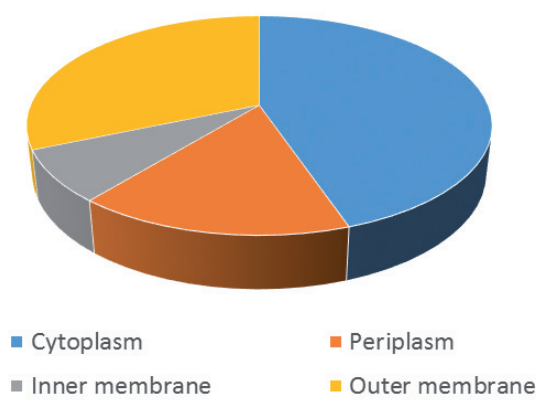

(b)

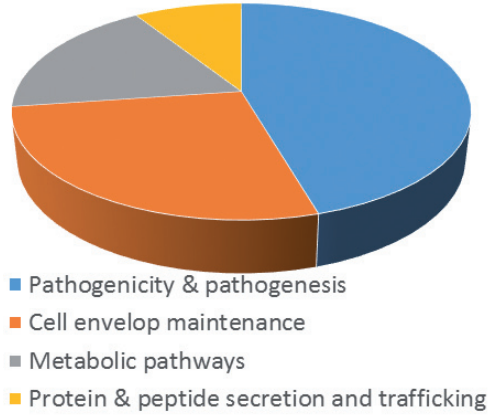

Fig. 2

Pie diagram of identified immunoreactive proteins extracted by TCA from C. burnetii

(a) Cell compartment localization; (b) Functional ontology.

The function was assigned to all identified proteins using UniProt database and then sorted into four groups (Fig. 2b). Proteins involved in pathogenicity \& pathogenesis were the most frequent (41.66\%), the second group corresponds to the cell envelope maintenance (25\%), followed by metabolic pathways (16.66\%). The last group is formed by proteins involved in protein \& peptide secretion and trafficking (8.3\%) (Fig. 2b).

Immunoblot analysis detected 12 immunoreactive proteins (Fig. 1b, Table 2). Interestingly, four of them may have moonlighting activity. All these proteins have been previously reported in other studies (Flores-Ramirez et al., 2017; Chen et al., 2011; Papadioti et al., 2011; Sekeyova et al., 2009; Beare et al., 2008; Jian et al., 2014, Toman et al., 2013). These include the general markers for Q fever chaperones $60 \mathrm{kDa}$ (Groel) and the chaperonin dnaK ( Xiong et al 2012) as well as the virulent factors (ompH and Mip), markers for acute Q fever (the omp's AdA and com1), and another stress protein with moonlighting activity (superoxide dismutase [Fe] sodB) that are involved in pathogenesis and pathogenicity (Flores-Ramirez et al., 2014; Skultety et al., 2011). The component of the tol-pal system ybgF which mediates the peptidoglycan synthesis and outer membrane constriction during cell division (Deringer et al., 2011) and the marker of acute $\mathrm{Q}$ fever (omp-A like protein CBU_0307) participate in the stabilization and maintenance of the cell envelope. The secB is engaged in protein trafficking. The glycine cleavage system protein $\mathrm{H}(\mathrm{gcvH})$, malate dehydrogenase (mdh), and fructose-bisphosphate aldolase (fabA) are metabolic enzymes. The last one is involved in the glycolysis and gluconeogenesis with virulence function in several bacteria (Shams et al., 2014).

\section{Conclusion}

In this work proteomic approach based on 2-D electrophoresis, mass spectrometry, and bioinformatics was employed to identify and characterize the protein composition of the soluble antigen possessing phase I antigen reactivity that was used as a chemovaccine against $Q$ fever in men. It was successfully administered in the past to more than 1700 volunteers. The vaccine was prepared from $C$. burnetii cells of strain Nine Mile EP3 in phase I using TCA extraction under the optimal conditions.

The proteomic analysis resulted in the identification of 39 unique proteins of $C$. burnetii from which 12 were recognized as immunoreactive. The localization and function of these proteins were assigned by bioinformatics. It was suggested that the identified proteins are primarily extracted from the surface of the C. burnetii cells. These proteins may form a part of the active components of the vaccine, which challenges the immune system of the host to generate antibodies that can fight the disease. Nevertheless, further studies have to be performed to analyze the proteins and the saccharide moiety of the extract which is involved in inducing protection. Because, some proteins, if included in the vaccine, may be immunosuppressive, whereas in other cases immune responses to some proteins may actually enhance disease. Thus, it is critical to identify those proteins that are essential for inducing protection and eliminate the others.

Acknowledgements. This work was supported by the following grants: 2/0173/15 and 2/0144/15 of the Scientific Grant Agency of the Ministry of Education of the Slovak Republic, the grant 21610493 of the International Visegrad Fund, and the grant 26240220096 of the Research \& Development Operational Programme funded by the ERDF.

\section{References}

Arricau-Bouvery N, Rodolakis A (2005): Is Q fever an emerging or re-emerging zoonosis? Vet. Res. 36, 327-349. https:// doi.org/10.1051/vetres:2005010

Beare PA, Chen C, Bouman T, Pablo J, Unal B, Cockrell DC, Brown WC, Barbian KD, Porcella SF, Samuel JE, Felgner 
PL, Heinzen RA (2008): Candidate antigens for Q fever serodiagnosis revealed by immunoscreening of a Coxiella burnetii protein microarray. Clin. Vaccine Immunol. 15, 1771-1779. https://doi.org/10.1128/CVI.00300-08

Chen C, Dow C, Wang P, Sidney J, Read A, Harmsen A, Samuel JE, Peters B (2011): Identification of CD4+ T cell epitopes in $\mathrm{C}$. burnetii antigens targeted by antibody responses. Plos One 6, e17712. https://doi.org/10.1371/journal. pone. 0017712

Deringer JR, Chen C, Samuel JE, Brown WC (2011): Immunoreactive Coxiella burnetii Nine Mile proteins separated by $2 \mathrm{D}$ electrophoresis and identified by tandem mass spectrometry. Microbiology 157, 526-542. https://doi. org/10.1099/mic.0.043513-0

Dorko E, Kalinova Z, Weissova T, Pilipcinec E (2008): Seroprevalence of antibodies to Coxiella burnetii among employees of the Veterinary University in Kosice, eastern Slovakia. Ann. Agric. Environ. Med. 15, 119-124.

Dorko E, Rimarova K, Pilipcinec E (2012): Influence of the environment and occupational exposure on the occurrence of $\mathrm{Q}$ fever. Cent. Eur. J. Public. Health 20, 208-214.

Flores Ramirez G, Jankovicova B, Bilkova Z, Miernyk JA, Skultety L (2014): Identification of Coxiella burnetii SurfaceExposed and Cell Envelope Associated Proteins Using a Combined Bioinformatics plus Proteomics Strategy. Proteomics 16, 1868-1881. https://doi.org/10.1002/ pmic. 201300338

Flores-Ramirez G, Danchenko M, Quevedo-Díaz M, Skultety L (2017): Reliable tool for detection of novel Coxiella burnetii antigens, using immobilized human polyclonal antibodies. J. Chromatogr. B 1047, 84-91. https://doi. org/10.1016/j.jchromb.2016.08.044

Fricova M, Janok J, Lukacova, Rojkovic D, Tarabcak M, Wilner L (1967): Epidémia Q horúčky vo Svidníku. Bratisl. Lek. Listy 48, 233-242.

Fries LF, Waag DM, Williams JC (1993): Safety and immunogenicity in human volunteers of a Lichloroformmethanol residue vaccine for Q fever. Infect. Immun. 61, 1251-1258.

Georgiev M, Afonso A, Neubauer H, Needham H, Rodolaskis A, Roest HJ, Stark KD, Vellema P, Van Der Hoek W, More SJ (2013): Q fever in humans and farm animals in four European countries, 1982-2010. Euro Surveill. 18, pii=20407. Available online: http://www.eurosurveillance. org/ViewArticle.aspx? ArticleId=20407

Gyuranecz M, Sulyok K, Balla E, Mag T, Balazs A, Simor Z, Denes B, Hornok S, Bajnoczi P, Hornstra H, Pearson T, Keim P, Dan A (2014): Q fever epidemic in Hungary, April to July 2013. Euro Surveill. 19, pii=20863. https://doi. org/10.2807/1560-7917.ES2014.19.30.20863

Hendrix LR, Chen CH (2012): Antigenic Analysis for Vaccines and Diagnostics. In Toman R et al. (Ed.): The Coxiella burnetii: Recent advances and new perspectives in research of the Q fever bacterium. Springer : Berlin, pp. 299-328. https:// doi.org/10.1007/978-94-007-4315-1_16

Janok J, Lukacova K, Rojkovic D (1964): Epidémia Q horúčky v Bardejovskom okrese. Bratisl. Lek. Listy 44, 281-287 (in Slovak).
Kazar J, Brezina R, Schramek S, Kovacova E, Urvolgyi J, Tvrda B, Palanova A (1983): Doterajšie skúsenosti s očkovaním ludí proti Q horúčke u nás. Bratisl. Lek. Listy $80,31-38$ (in Slovak).

Kazar J, Gajdosova E, Kovacova E, Valkova D (1982): Immunogenicity and reactogenicity of a $\mathrm{Q}$ fever chemovaccine in persons professionally exposed to $\mathrm{Q}$ fever in Czechoslovakia. B. World Health Organ. 60, 389-394.

Kazar J, Schramek S, Brezina R (1978): Immunological properties of the lipopolysaccharide-protein complex of Coxiella burnetii. Acta Virol. 22, 309-315.

Kersh GJ, Fitzpatrick KA, Self JS, Biggerstaff BJ, Massung RF (2013): Long-term immune responses to Coxiella burnetii after vaccination. Clin. Vaccine Immunol. 20, 129-133. https:// doi.org/10.1128/CVI.00613-12

Kováčová E, Kazár J (2002): Q fever - still a query and underestimated infectious disease. Acta Virol. 46, 193-210.

Kováčová E, Kazár J, Španělová D (1998): Suitability of various Coxiella burnetii antigen preparations for detection of serum antibodies by various test. Acta Virol. 42, 365-368.

Literak I, Rehacek J (1996): Q fever - distribution and importance of this disease in the Czech Republic and in the Slovak Republic. Vet. Med. 41, 45-63.

Lukáčová M, Brezina R, Schramek S, Pastorek J (1989): Chemical composition of phase I Coxiella burnetii soluble antigen prepared by trichloroacetic acid extraction. Acta Virol. $33,75-80$.

Mittermayer T, Scheidova L, Tarabcak M, Milosovicova A, Zelenakova V (1964): Epidémia Q horúčky v Košickom okrese. Bratisl. Lek. Listy 44, 288-295 (in Slovak).

Oyston PCF, Davies C (2011): Q fever: The neglected biothreat agent. J. Med. Microbiol. 60, 9-21. https://doi. org/10.1099/jmm.0.024778-0

Parker NR, Barralet JH, Bell AM (2006): Q fever. Lancet 367, 679688. https://doi.org/10.1016/S0140-6736(06)68266-4

Papadioti A, Markoutsa S, Vranakis I, Tselentis Y, Karas M, Psaroulaki A, Tsiotis $G$ (2011): A proteomic approach to investigate the differential antigenic profile of two Coxiella burnetii strains. J. Proteomics 74, 1150-1159. https://doi. org/10.1016/j.jprot.2011.04.016

Porter SR, Czaplicki G, Mainil J, Guatteo R, Saegerman C (2011): $\mathrm{Q}$ fever: Current state of knowledge and perspectives of research of a neglected zoonosis. Int. J. Microbiol. 186, 7344-7352. https://doi.org/10.1155/2011/248418

Rehacek J (1987): Epidemiology and significance of Q fever in Czechoslovaquia. Zbl. Bakt-Int. J. Med. M. 267, 16-19.

Rehacek J, Kocianova E, Kovacova E (1996): Contamination in areas of Slovakia with strains of Coxiella burnetii imported from abroad. Vet. Med. 41, 173-176.

Ruiz S, Wolfe DN (2014): Vaccination against $Q$ fever for biodefense and public health indications. Front. Microbiol. 5, 1-7. https://doi.org/10.3389/fmicb.2014.00726

Sadecky E, Abel J (1978): Vakcinácia hovädzieho dobytka proti Q horúčke v okrese Bratislava-vidiek. Vet. Med. 23, 719-725 (in Slovak).

Sellens E, Norris JM, Dhand NK, Heller J, Hayes L, Gidding HF, Willaby H, Wood N, Bosward KL (2016): Q fever knowledge, attitudes and vaccination status of Australia's veterinary 
workforce in 2014. Plos One 11, e0146819. https://doi. org/10.1371/journal.pone.0146819

Sekeyova Z, Kowalczewska M, Decloquement P, Pelletier N, Spitalska E, Raoult D (2009). Identification of protein candidates for the serodiagnosis of $\mathrm{Q}$ fever endocarditis by an immunoproteomic approach. Eur. J. Clin. Microbiol. Infect. Dis. 28, 287-295. https://doi.org/10.1007/ s10096-008-0621-4

Shams F, Oldfield NJ, Wooldridge KG, Turner DP (2014): Fructose1,6-bisphosphate aldolase (FBA)-a conserved glycolytic enzyme with virulence functions in bacteria: 'ill met by moonlight'. Biochem. Soc. Trans. 42, 1792-1795. https:// doi.org/10.1042/BST20140203

Skultety L, Hajduch M, Flores-Ramirez G, Miernyk JA, Ciampor F, Toman R, Sekeyova Z (2011): Proteomic comparison of virulent phase I and avirulent phase II of Coxiella burnetii, the causative agent of Q fever. J. Proteomics 74, 1974-1984. https://doi.org/10.1016/j.jprot.2011.05.017

Toman R, Škultéty L, Palkovičová K, Florez-Ramirez G, Vadovič P (2013): Recent progress in glycomics and proteomics of the Q fever bacterium Coxiella burnetii. Acta Virol. 57, 229-237. https://doi.org/10.4149/av $201302 \quad 229$

Trubiano JA, Holmes NE, Williams DS, Ng J, Chua K, Howden B P (2012): Coxiella burnetii endocarditis after Q fever vaccination. J. Med. Microbiol. 61, 1775-1779. https:// doi.org/10.1099/jmm.0.050880-0

Van Der Hoek W, Dijstra F, Wijers N, Rietveld A, Wijkmans CJ, van Steenbergen JE, Notermans DW, Schneeberger PM (2010): Three years of Q fever in the Netherlands: faster diagnosis. Ned. Tijdschr. Geneeskd. 154, A1845.

Varga V (1997): An explosive outbreak of Q-fever in Jedlové Kostolany, Slovakia. Cent. Eur. J. Public. Health 5, 180-182.

Waag DM, England MJ, Tammariello RF, Byrne WR, Gibbs P, Banfield CM, Pitt MLM (2002): Comparative efficacy and immunogenicity of $\mathrm{Q}$ fever chloroform: methanol residue (CMR) and phase I cellular (Q-Vax) vaccines in cynomolgus monkeys challenged by aerosol. Vaccine 20, 2623-2634. https://doi.org/10.1016/S0264-410$\mathrm{X}(02) 00176-7$

Waag DM (2007): Coxiella burnetii: Host and bacterial responses to infection. Vaccine 25, 7288-7295. https://doi. org/10.1016/j.vaccine.2007.08.002

Xiong X, Wang X, Wen B, Graves S, Stenos J (2012): Potential serodiagnostic markers for $\mathrm{Q}$ fever identified in Coxiella burnetii by immunoproteomic, and protein microarray approaches. BMC Microbiol. 12, 35. https://doi. org/10.1186/1471-2180-12-35 